\title{
THE BASIC PRINCIPLES OF MEDICINE IN THE PRIMITIVE MIND*
}

\author{
by
}

\section{CHARLES COURY}

THE DESIRE to maintain, reinforce or restore health, has everywhere followed initially two distinct trends-that of instinctive or empirical medicine, and that of magic or sacerdotal medicine. The fusion of these two - accidental at first, then systematic and by intent-had as a happy and paradoxical consequence the progressive laicization of the profession; a preliminary condition necessary to its development.

Instinctive and empirical medicine has had to start with a very limited field of action-that of morbid conditions, the cause or the agent of which is evident and directly recognizable. This means that it applied itself mainly to superficial traumatic complaints.

Long before the appearance of Homo Sapiens, the instinct of the animals had taught them how to immobilize a broken leg; to lick a wound; to get rid of a thorn; or even to absorb a purgative herb. Pliny considers that animal medicine has directly inspired that of man. Then man put to the service of his own instinct the resources of an elementary logic.

Later, medical empirical knowledge was born from occasional and repeated findings, and from remembering and recording certain happy results fortuitously obtained. At this stage man learned how to summarily reduce, and later how to immobilize a fracture or a luxation; how to extract an accessible foreign body, manifestly causing his pain; and how to resort to baths and diet. The relief brought about by the spontaneous opening of an abscess prompted him to incise, with a stone splinter or a bronze blade, the superficial collections of pus. Aware of the fact that repeated ingestion of the same noxious substance regularly brings about the same disorders, he doubtless and precociously had the idea of evacuating it as soon as possible by using vegetable drugs, of which he had noticed the emetic or purgative effects. Through the following ages, intuitive and intelligent empiricism has been at the origin of countless therapeutic discoveries. Fortuitous comparisons probably brought to light, in the East or in Byzantium, the antigouty virtues of colchicum; and thanks to the same mental process, the American Indian tribes used for the first time the febrifuge action of cinchona bark and the antidiarrhoeic effect of ipecacuanha. For having at all times practised deep-sea fishing, the natives of Polynesia spontaneously conceived artificial breathing in case of drowning. Many other similar examples could indeed be quoted.

Medical empiricism has thus been the earliest precursor of observation, and later of experimental medicine. It seems to have existed in the remotest times, and one

\footnotetext{
*A lecture given at the Wellcome Historical Medical Library on 12 July 1966. The author is highly indebted to Mr. and Mrs. James Black for their help in the translation.
} 


\section{Coury}

finds its first historical trace in the therapeutic inscription appearing on the famous Nippur tablet, dating back to the twenty-first century B.C. In China, Babylonia, Egypt, and even ancient America, this form of medical activity developed in a parallel direction to sacred medicine, and independently of it, so as to become the attribute of the physicians proper-free of any religious obedience. In China, as early as the second millenium B.C., the practitioner or 'yi' was already distinguishable from the sorcerer or 'wou'; as in the time of the Pharaohs the 'wabu' exorcist differed from the lay practitioner. In Babylonia, the term 'asipatu' applied to the witch-doctor, while 'asûtu' applied to the real physician. Likewise, the pre-Pizaro Peruvians had the choice between the 'ichuri's' occult art and the 'sancoyoc's' empirical knowledge. As René Labat warns, 'One should not assume that medicine slowly and laboriously freed itself from magic art by a sort of progressive triumph of reason over the spirit of superstition. From our very earliest textual references we notice, on the contrary, that medicine and magic have at all times coexisted as two autonomous and often complementary disciplines.' Most often neither of them applied to the same cases nor to the same illnesses. Religious medicine has indeed borrowed from empirical medicine, ostensibly or not, in an ever larger proportion; but it nonetheless represents the most widespread and the most general aspect of archaic medicine.

Magic and sacerdotal medicine, as a matter of fact, sums up most of the initial features of the art of healing. It applies to the so-called internal complaints, as long as their seat remains unknown and their provocative agent undisclosed. Analogous to the action of foreign bodies, most of these complaints have very soon been imputed to the action of invisible forces-immaterial rather than material; and in any event mysterious. For lack of anatomical and physiological knowledge, primitive man transposes any pathogenic concern to the supernatural field. Illness is thus considered as an independent presence, temporarily harboured in man, and yet still alien to him. Symptoms are nothing but the secondary outbreaks of the internal presence of this transcendental parasite which physically 'possesses' the patient. Icterus for example shows the presence of a yellow demon; convulsions are nothing but motions imparted to the patient by the restless entity which is inside him and dominates him. These concepts have for a long time survived the birth of Greek and Roman civilizations; they were still ruling exclusively in Hellas of Homer's days, and among the Italic peoples.

The mysterious entity which constitutes and causes illness can only be approached with some chance of success by those who know how to command occult forces and have the power or the means to influence them.

In the beginning, therefore, the practitioner will be 'the magician' or 'the sorcerer', a powerful and dreaded personality. He acts by mobilizing and mainly controlling the invisible forces; he uses them directly and without any intermediary, with a benefic or malefic purpose according to each case. The first known representation of the witch-doctor is probably that on the wall of the prehistoric cave of the 'Three Brothers' in France, in the Ariège department. It pictures an anthropomorphous bearded figure clothed in an animal skin and with reindeer's antlers on his head.

The sorcerer or the fetish-priest, whom the Africans of the present day call by the name of 'nganga', distinguishes himself less by a predestination with which he is 


\section{Basic Principles of Medicine in the Primitive Mind}

credited than by his gift of intuition, by the relative level of his practical education, and even more by the sound knowledge he has of primitive psychology. He often owes his learning to a subtle initiation or to a long apprenticeship in which the empirical experiences of his predecessors play a great part. Thanks to his skill and sense of opportunity, he knows how to take advantage of a few confirmed prognostic deductions, or a few successful therapeutic accomplishments in order to exert an almost divine influence on his practice. Understandably he keeps jealously secret the few recipes-generally empirical - to which he owes such a privileged position; and he carefully maintains in his behaviour and his dress the characteristics of mystery and strangeness with which a credulous environment invests him. In primitive communities the medicine-man rapidly tends to become the king-magician. The eastern Mediterranean and later the Jewish and Arab cultures, the Precolumbian civilization, and the Greco-Latin world have all widely practised magic; it survived the spreading of Christianity and flourished during the Middle Ages and the Renaissance-it still exists today, confined in an attractive clandestinity.

Religious medicine was born as soon as most of the near or remote cosmic elements were deified. Contenau summarizes the problem in a few words; what he writes about the Assyrians and the Babylonians applies as well to all the other theocratic communities such as those of Vedic India, ancient Egypt, or the Mayan, Inca and Aztec empires: 'The god is the true master of all that man has created, and of man himself: he strikes with disease those whom he chooses to strike; the sole resource against any illness is to appease the god; to move him to mercy is a matter for his ministers, whether it is a case of physical or mental disorder. It is therefore natural that the physician belong to the class of the priests, especially as that class alone is in possession of the knowledge.'

Actually, the priest achieves a result similar to that of the sorcerer, by virtue of rather closely related principles. But unlike the magician, he performs through a transcendental power-deity, demon or genius-responsible for the sickness or able to abolish it, and whose intervention or forgiveness he seeks.

The diagnosis therefore consists in recognizing the causal power and in discovering, as much as possible, the motives which prompted it. As a general rule, disease is considered as a punishment which the gods inflict on man to chastise him for a crime, an impiousness, a negligence towards them, or for breach of taboo. The individual concerned is, besides, not necessarily conscious of the offence he has committed: the soothsayer then endeavours to reveal it to him. This concept of the disease as a sanction was current in the eastern Mediterranean and in Precolumbian America; it is also fundamental in the Bible, and is still widespread nowadays among the African tribes. Illness can also result from the vengeance or the hatred of a god. This divine hostility may be individual or collective; Jahveh would readily inflict cruel plagues on his people or his enemies; in Babylonia epidemics were described as 'a devouring activity of the god'. The same deity is moreover equally able to cause the disease or to heal it, according to its intentions-as a magician is supposed to be able to drive the sickness out, as in white magic; or to infuse it, as in black magic.

Next to the principal gods, the demons play a very important part in the origin of diseases. The Mesopotamians referred to them by the name of 'ekimmu', and in the 


\section{Coury}

Middle Ages they were identified with the 'devils' of hell. In our time, the natives of Malaysia call them 'bantu'; the Africans of Low-Casamance 'boekin'; and those of Low-Congo 'ndoki'. Each country, each era, has had one or several different terms for them.

Almost all deities enjoy among their attributes a certain medical power. But some of them have, in a more particular way, the faculty of making sick or of healing; they protect and inspire more directly the physician-priests. Certain medical pantheons are very richly peopled-the medicine-man, whether priest or sorcerer, must then be careful to call selectively the genius specialized in the relevant disorder. In Egypt, Isis and Thot dispose of magic therapeutic formulae, and Sekhmet knows of efficient drugs; Seth has the double power to loose epidemic diseases or to ward them off, Douaou knows how to treat eye conditions and Meret-Seger snake bites, Thaouris presides over child-birth and infant welfare; the great practitioner Imhotep himself will eventually be deified, as will later on Aesculapius, by the Greeks. For the peoples between the Tigris and Euphrates, the demon Axaxazu engendered icterus, and Ashku phthisis; Cemashtu attacked children and pregnant women; the goddess Gula, wife of Ninurta, was the 'great woman doctor'. The cross-eyed god of the Mayas, Itzamna, was considered as the patron of the physicians. The Incas often called upon a special demon who was a master at fighting poison. Among the Aztecs, Tlaloc the rain god dispensed or cured, as the case may be, dropsy, climatic complaints, leprosy, and other skin diseases; Ciuapipiltin was responsible for convulsions and the paralytic conditions of children; Xipe Totec caused ophthalmias; Ixtlitlton was more specially invoked in pediatrics, Xochipilli against venereal diseases and haemorrhoids, and the goddess Coatlicue intervened in obstetrics. Zamolxis among the Dacians, Darzos among the Getae of Rumania, and Bendis in Thrace, counted among their functions that of healing. The present Diola populations of Low-Casamance and Portuguese Guinea number at least some twenty 'pathogenic' evil spirits: Kahan who dispenses leprosy, Kanelak who provokes varicosities, Fimof who causes mental disorders; Kanfasa induces dystocias, Hufila brings about otitis, and so forth. So has the 1957 smallpox epidemic revived the belief in a long forgotten 'boekin' (Kerharo and Thomas).

Especially in its most insidious and prolonged forms, physical or mental sickness may also be the act of a human being exerting a malefic power at a distance, of an unsatisfied or vengeful spirit coming back as a ghost, or even of an enemy or a living rival. This morbific action of the 'evil eye', the 'jettatura', the spell, or the evil spirits, is a manifestation of 'black magic' which has at all times occupied a very important place in folk belief; it has always been taken into consideration in traditional jurisdictions, regarded as a criminal act, and severely punished.

Therefore, the identification of the pathogenic agent-that is the supernatural power involved-represents the fundamental initial step of the magico-medical act. In Uganda, the tribal practitioner questions his divining fetish in such terms: 'Is such-and-such a god angry? Is ancestor so-and-so complaining he is forgotten? Has individual so-and-so cast a spell?', and so forth.

The next step is the prognosis. It informs the patient and his entourage on the form the sickness will take; and what is more, it lets the therapeutist know what he 


\section{Basic Principles of Medicine in the Primitive Mind}

is entitled to expect from his intervention. In Egyptian medicine, for instance, obviously incurable diseases were not to be subject to treatment-without our even knowing whether this abstention was meant to relieve the practitioner in advance of his responsibility in facing a sure failure, or not dangerously to oppose the deity's unyielding will. This negative attitude, this refusal to act in hopeless cases appears again in the Hippocratic Collection. The empiricist drew prognostic conclusions from the patient's major symptoms-the admirable Egyptian medical papyri and the Assyrian and Babylonian clay tablets provide many striking examples of these conclusions. As for the sorcerer and the priest, they resorted to divination and drew their inspiration from omens. Omens, to a great extent, originated from the idea that the human microcosm is in constant relationship with the macrocosm. This mythical allegiance of man to universe explains the meanings attached to meteorological and astronomical phenomena. Other factors also intervened, such as the contrast between the right side, reputed favourable - and the left, deemed ill-fated.

Long before Pythagoras, the study of numbers, probably based on a few initial empirical data, played an outstanding part which foretells the notion of the 'critical days' as Hippocratic medicine will later conceive it. The Mesopotamian haruspices, or 'barous', attached a great importance to the configuration of the inferior surface of the liver of sacrificed animals; this soothsaying through hepatoscopy, later played a prominent part among the Etruscans.

Divination implies, on the sorcerer's or the priest's part, a direct contact with the supernatural world, by virtue of their extrasensory perception or their close relationship with deities. Among certain peoples, and in India more particularly, fasting, mortifying of the flesh, mental concentration, or certain peculiar physical practices are reputed to increase the gift of second sight. The Precolumbians' dreams were interpreted as a communication with the beyond and were encouraged by the absorption of alcohol and by the use of hypnotic or hallucinogenic drugs extracted from certain mushrooms.

Prognostic divination may be the occasion for a genuine liturgical setting. As an example, Kerharo and Thomas report an interesting formula used among the present day fetish-priests of West Africa; it includes a prayer which accompanies the sacrifice of a white hen, and translates roughly as follows: 'I salute you, Boekin, father of us. Our big one is sick a lot. This is why we come for you to help us.' If the sin committed is too great and the verdict unfavourable, the answer is then: 'I have made the sacrifice.' But Boekin has said, 'So-and-so must die; he has offended Boekin too much'.

But in many cases the act of divination, surrounded with more or less strange exterior manifestations calculated to strike public imagination, is nothing but a fraud intended to give more weight to an evident finding or to the conclusions of an intelligent empiricism.

Apart from a few valuable contributions they owe to empiricism, primitive therapeutics appear to the modern physician irrational, whimsical and disconcerting to say the least. They are, however, based upon a few general principles which make them less incomprehensible. Most of them more or less directly originated from a certain number of fundamental beliefs born very early in man's mind. Many of these concepts find their expression in very ancient sociological phenomena which were common to 


\section{Coury}

most primitive cults and are called rites. Sir James Frazer made of them a remarkable analysis in his famous Golden Bough, named after a picture by Turner.

The law of 'correspondence' or 'cosmic participation' asserts the existence of a more or less close relationship between human nature and the universe in which it moves. This concept later on inspired a series of medico-philosophical doctrines, one of which is atomism.

The liberation of immaterial forces, prompted by divine power or by magical art, is one of the essential postulates, solidly anchored in the mentality of primitive men and of the mystics. These forces however require control by him who releases them, failing which they might break out freely and even strike back at their promoter.

The principle of solidarity or 'contagion' (Frazer) implies a permanent continuity between the human being and what has belonged to him or what has come into contact with him, even in case of physical separation. So are natural products like cut hair, nail clippings, discharged excrements, and familiar objects such as old clothing, scrapped weapons or tools, an integral part of their ancient proprietor, even at a distance. They thereby lend weight to the magic practices, whether benefic or malefic, that concern him. Melanesian sorcerers owe their prestige and wealth to their power of inflicting and warding off sickness at will by ritually burning their victims' dung. Likewise the famous 'powder of sympathy' (which the seventeenth century quacks dispensed at huge prices) acted by simple application on a dressing that had been used by the wounded, 'even though he were a thousand leagues away from the cloth on which the powder is applied.' This solidarity spreads to the subject's shadow, believed to be indissociable from him-to his footsteps-and even to his name, considered as the most perfect expression of his personality.

The mere fact of uttering a name is endowed with a power of material evocationas the old saying goes, 'Talk of the devil, and he will appear.' It would be imprudent to pronounce an ill-fated word without previously conjuring it by an appropriate formula. Telling one's true name to a stranger amounts to putting oneself in his power, in case he would use it as a magic support to evil spells. In ancient Mediterranean civilizations, the practitioner sometimes forced his patient to change his name in order to escape illness. And inversely, the Egyptian witch-doctor could not perform efficiently without previously knowing the correct name of the person to be cured. Eager to know her father Rê's real name, Isis forced him by trickery to reveal it to her. Having stirred up a snake which bit him cruelly, she declared herself unable to relieve him as long as he would not confide to her the supreme secret which she was burning to know. Horus used the same stratagem with his brother.

This fear that the rash disclosure of a name would make its bearer vulnerable was current among the peoples of the eastern Mediterranean. Facing the Burning Bush, Moses alone had the privilege to hear from the Almighty's mouth that God intended to be called 'Jahveh',-in other words 'The One who is'; but the Hebrews refrained from using this name and merely called him 'Elohim', the Lord. Understandably, the nominal identity of human beings must be carefully kept, even beyond death; and the use of funeral inscriptions is an evidence of this belief. In the Egyptian liturgy, the first step taken by the deceased in the presence of the divine tribunal was to proclaim his name. When a Pharaoh defaced the carved name of one of his predecessors in 


\section{Basic Principles of Medicine in the Primitive Mind}

order to replace it by his own, not only did he falsify an historical reference, but he actually substituted himself for his predecessor and assumed his merits. This importance of the proper noun is no more than a peculiar aspect of the belief in the power of names, which had lasting magico-medical significance and to which we will have to come back.

The belief in 'action by sympathy or by telepathy' plays a considerable part in magic art. It admits that it is possible to transfer immaterial forces from one man to another, or from a human being to an animal, or even to an object. This transference can be brought about at a distance or by contact, and can take place both ways. It is thus possible to shift the sickness of one suffering individual to a healthy individual; and inversely, a healthy being may provide the elements which a patient is missing, by virtue of a kind of immaterial opotherapy. This possibility of transference is the basis of numerous rites, called 'substitution rites', which primitive medical systems have very widely used and of which we will give a few examples later.

Magic medicine which readily transforms simple coincidences in causalities, equally believes in 'synergic or antagonistic interactions between similar elements.' The notion of similarity must here be understood in a very wide sense. It can express the connection existing between an individual and his own image in a mirror, or between a living being and his effigy. The latter may be a symbolic representation drawn or painted on a wall (pre- or protohistorical cave-paintings in France, Spain or Africa), clay model (archaic anthropomorphous pottery), a sculpture elaborated in stone by an artist, or a figurine roughly shaped by a sorcerer. Several transference or substitution rites rely on this belief. It also gave birth to the method of 'treatment by similars' which goes much further back than the time of Hippocrates: a passage from the Kahoun gynaecological papyrus (1950 B.C.) recommends that women whose vaginal discharge smelt of burnt meat should be exposed to the same fumes of burnt meat.

In a wider sense, the magicians' similarity includes a much more remote relationship, of a strictly formal order, such as simple homonymies. Others have as a starting point an association of ideas, an analogy or an allusion: thus, the fact of spilling a water libation, or even of weeping, calls for rain; any part from an elephant, a hair for instance, is supposed to protect man's dentition, for no other reason than this animal's tusks represent an impressive dental display. Stephen-Chauvet reports, that in order to help cutaneous eruptions 'to get back under the skin', certain African fetishpriests prescribe a medication containing a piece of turtle neck, this animal having the property of retracting its head under its shell.

Elsewhere, the connection between both terms is exclusively morphological: folk belief has always assigned strange powers to the mandrake because it vaguely asumes a human shape. The medical doctrine of 'signatures', which Paracelsus again developed in the sixteenth century, draws its inspiration from the same principle: the hepatica leaf being trilobate as the liver is, it cannot fail to have therapeutic action on this organ; likewise the bean on the kidney and the walnut on the brain; the ruby, the colour of which is that of fresh blood, has the power to stop haemorrhages.

Magic symbols go even further. Without entering the field of esoteric transpositions, let us merely recall the purifying property of water, the dissolving action of fire, the value of certain colours, the meaning ascribed to triangular figures, the compelling 


\section{Coury}

power of circles, the interrupting capacity of knots, the determining virtues, whether of good or bad omen, of certain numbers, and as a consequence of verbal repetitions and incantation rythms.

At a more or less early stage of their development, almost all civilizations have granted a leading part to the 'proper action of words' and have applied it to the art of healing. From the first verses of Genesis to the Gospel according to St. John, the divine and creative power of the Word is one of the dominant elements of the Jewish and Christian metaphysics. If words have the power of creating the world, how could they not have that of freeing it from evil? Talking of the Lord, the Psalmist says, ' $\mathrm{He}$ sendeth his word, and healeth them.' (Psalms, CVII, 20). Like those of the gods, human words, if they be pronounced in conformity with very strict rules, materialize will and invest it with a supernatural power. As a matter of fact, the intrinsic virtue of the formula lies less in its substance or in the intention that motivates it than in its verbal and sonorous structure; it is often made more striking through artifice of style, rhythm, alliteration or repetition which adds the power of numbers to the power of words. Once it has been spoken, the ritual sentence is irrevocable, even in case of error. Its efficacy is assured: 'So shall my word be that goeth forth out of my mouth: it shall not return unto me void, but it shall accomplish that which I please, and it shall prosper in the thing whereto I sent it.' (Isaiah, LV, 11).

Of course, the meaning, the form, and the scope of therapeutic formulae, vary with the capacity or the functions of him who uses them. In the form of spells or incantations, the medicine man recites direct formulae of conjuration. The most common ones are an order given to the ailment or to its author to release the patient; if necessary the injunction is accompanied by threats-or it aims at diverting the responsible agent from his intentions by opposing his will, by disclosing and proclaiming his name in order to place him in a position of inferiority. In other cases the method consists in asserting repeatedly that the patient is healthy, cured, or protected against disease - the words uttered having the effect of creating their own object and identifying themselves with it. In his capacity of intercessor, the priest performs by means of exorcism or prayers; in both cases he calls upon the intervention of a supernatural power. He begs for the help of the god involved by invoking his name in the established format. Should he believe the illness to be the result of punishment or retaliation, he implores the forgiveness of the offended deity and, if needed, offers a compensation, especially in the form of an expiatory sacrifice. He sometimes ventures to threaten the god, while taking refuge behind the authority of a more powerful or antagonistic deity of which he claims to be the interpreter. In certain instances the priest even identifies himself with the god he is invoking, so as to exert more influence on him, or at least to answer favourably in his name.

The spoken word-whether spell or prayer-often benefits by being associated with 'movement', which makes the initiate more apt to fight against the demoniac forces. This dramatic action may be restricted to imposition of hands, mimicry, or established gestures. It reaches its most elaborate symbolic expression in ritual dances, often with fancy-dress and masks, where sham, antithesis, substitution and orison constitute common figures, but so closely intertwined that it is almost always very difficult to identify them. And yet this long enumeration of beliefs and rites is very incomplete. In 


\section{Basic Principles of Medicine in the Primitive Mind}

primitive medical practice, these various elements of faith and superstition are almost always linked together-which adds even more to the complexity of the methods of treatment and gives them this appearance of incoherent strangeness they most often assume in our eye.

Countless documents, as well as other early and recent evidences, throw light upon the manner in which principles of magic and religious beliefs have been applied to the art of healing. The preceding analytical study has already provided us with a few examples of this application. The object of the following ones, chosen among many others, is to give a bold outline of the general procedures of primitive therapeutics of which too many remnants still hide themselves in our time on the fringe of scientific medicine.

Most of the methods used by medicine men or temple priests aim at freeing the patient from the morbific demon who is harboured in him. Again, it is often difficult to distinguish or dissociate the fundamental rules which inspire them, such has been their final degree of correlation with each other in an obscure syncretism. The Ebers papyrus $(1550$ B.C. $)$ provides a relatively simple example of simultaneous application of the principle of similarity and the substitution rite: to treat migraine, it is advisable to rub the aching area of the head with the head of a fish (similar element) which will pick up the ailment and rid the patient of it (phenomenon of substitution).

Therapy by speech or gesture occupies a prominent position in most primitive medical disciplines.

In order to drive away or ward off the demoniac or divine power responsible for the disease, the magician casts a conjuration spell. 'When you will have pronounced the incantation on the patient, he shall heal', says the Akkadian Treatise of Medical Diagnosis and Prognostics.

The priest recites a prayer and begs for the help of the deity: 'Goddess, Mother of mankind, thou who healest dissociated flesh, $O$ Mother of the living: headaches, toothaches, nausea, gripes, eye trouble, weakness, paralysis of the articulations, every bad illness, do drive away!' The priest may also proceed by exorcism: 'In the name of Heaven, let him be exorcised; in the name of Earth, let him be exorcised!' To make his orison more efficient, the priest may offer a 'libation' to the angry god or, even better, a 'sacrifice' in which the animal will intervene as a substitute: 'He has consigned the lamb against his life, he has consigned the head of the lamb against the head of the man, he has consigned the neck of the lamb against the neck of the man, he has consigned the breast of the lamb against the breast of the man.'

One could easily draw a parallel between these Assyrian and Babylonian texts and similar formulae borrowed from Pharaonic Egypt or from other early civilizations. The following one was used by the Aztecs against cephalea: 'I the priest, I the lord of enchantments, I want to cure this ailing flesh;... (I am asking) where is that which is destroying this bewitched head ... Oh wind, are you bringing the remedy for this bewitched head?-and at the same time, accompanying speech by gesture, the officiant blew on the patient's head which he held in his hands.

Speech is always necessary, but not always sufficient. And this is when the prescription of drugs intervenes; its relative importance grew with the development of civilizations and the progressive interference of empiricism. It is not my purpose to give an 


\section{Coury}

idea, even though succinct, of archaic pharmacopoeias which differ so much, according to the countries and the periods. The substances used vary from the most common to the rarest and most unusual, from the most pleasant, like rosewater, to the most nauseating, like gazelle dung mixed with beer yeast (Assyrian Medical Texts, $\mathrm{n}^{0} 191$, 12). Most of them are either vegetable or animal, and almost always used in complex compounds. Here again ritual formalism retains all its rights. Of great importance was the choice of every ingredient, its dose, and mainly the conditions under which it was collected. The absorption of the medicine was inevitably accompanied by the uttering of a rigid formula: 'They are coming, those medicaments, they are coming in order to drive away all sorts (of diseases) ... Incantations have a great power over remedies... Words (to be spoken) when the medicament is absorbed.'(Ebers Papyrus). Often was the formula much more obscure, esoteric, and at times even totally incomprehensible. However, the concern of carrying out the prescription to the letter could not fail to increase the effect of suggestion on the patient and, as a consequence, the efficacy of the drug.

Some medicines act 'by expulsion or evacuation' of the malevolent genius or his agent. Such is the case for the emetics, the purgatives and the enemas borrowed from empirical medicine. Known to the primitive men, bloodletting was originally inspired by the same principle. Like the clyster, it led later to the fashion and the abuses we all know of. A precursor of cupping, mouth suction is a means of purification often used by the sorcerers and magicians of the Old and the New World. The Baron de la Hontan, who lived in Canada from 1683 to 1693, described the way this method was used by the Iroquois: 'A juggler visits the patient, examines him quite earnestly and says, "If the evil spirit is here, we will quickly drive him out" ... The juggler sucks some part of the patient's body, pulls a few knuckle-bones from his own mouth, and tells him these same knuckle-bones have come out of his body... ' As a matter of fact, due to a psychotherapic concern, the performer makes a point of producing to the gullible patient the materialization of the discharged ailment in the shape of a nasty object or, merely, a pebble. Likewise were the 'head-stone' extractors very highly thought of in the Middle Ages for the treatment of alienation. And did there not appear, no further back than a few years ago, a charlatanic treatment of biliary lithiasis consisting of the patient's ingestion of a product which solidifies in the course of the digestive transit and reappears in the faeces in the shape of false stones?

When the evil spirit has settled down in an area of the body such as the head, from which it cannot easily be dislodged through natural ducts, it is logical to clear a way for it. And here we must give an important place to the famous skull trepanning of which so many evidences have been found not only on prehistoric skeletons, but also on human remains belonging to more recent, although still 'medically archaic' civilizations. But this subject, so often studied, would deserve by itself a long development that would overlap our purpose.

As has been pointed out before, the administering of substances apparently connected with the disease involved acts by virtue of the principle of 'interaction between similars'; saffron decoctions were taken to be a cure for jaundice, preparations based on eyes of reptiles were recommended for ophthalmias; against impotency, certain African sorcerers even prescribe a true endocrinal therapy in the form of an extract 


\section{Basic Principles of Medicine in the Primitive Mind}

of male impala's testes; absorption of sexual glands of wild beasts had already been proposed by the Chinese some 2000 years B.C. Thus, the origins of glandular therapy go back to the remotest times of magico-empirical medicine.

Another highly valued method of magic art consists in operating 'by repulsion'. The use of antagonists makes it possible to oppose the demon in his habits so as to compel him to vacate the sick man's body; cold baths used in febrile complaints are probably an example of this procedure, but are doubtless also due to empiricism or instinct. Under the Pharaohs, while treating her sick child with soothing and diaphoretic medicines, the Egyptian mother uttered the following conjuration formula: 'Vanish, demon who comes in the dark ... I I have prepared for him [the child] a magic remedy against you [the demon], consisting of melilot-which hurts you; onions-which harm you; honey, sweet to men but bitter to demons.' The use of revolting drugs, so widespread in ancient times and Middle Ages is more characteristic: the prescription of nauseating products, foul or excremental, which German authors group under the name of 'Dreckapotheke', aims at disgusting the demon and obtaining his escape. To say the truth, these picturesque compounds very often included in addition, one or several less unusual and more efficient elements. A sleeping formula recommended by the pediatrists of the Pharaonic era thus associated flies' dung with poppy seeds. Very early indeed did the wisest and most experienced medicine-men and temple priests skilfully utilize empirical methods for their own benefit. Under the impressive and theatrical mask of the supernatural, they brought in medicine 'natural' means so as to better ensure the success of their practices.

Next to verbal formulae and the administering of drugs, the substitutive method has at all times held a very important part in magic or sacerdotal medicine. Encouraged by conjuration and ritual practices, the transference of the disease is performed at the expense of a 'scapegoat', which can be a human being, an animal, a plant, and even an inanimate object.

Transference from man to man is obtained through a real voodoo in which the receiver, whether consenting or not, relieves the patient from his ailment by submitting himself to it. In certain instances, this receiver is no other than the magician who identifies himself mystically-or by simulation-to his patient.

When a Cingalese is dangerously ill, and the physicians can do nothing, a devil-dancer is called in, who by making offerings to the devils, and dancing in the masks appropriate to them, conjures these demons of disease, one after the other, out of the sick man's body and into his own. Having thus successfully extracted the cause of the malady, the artful dancer lies down on a bier, and shamming death is carried to an open place outside the village. Here, being left to himself, he soon comes to life again, and hastens back to claim his reward.

(Grunwedel, 1893, quoted by Frazer).

Transference to an animal is equally widespread among certain primitive peoples of Africa, South-East Asia and Indonesia. Its usual objective is to deliver the population from an epidemic plague with which one burdens, by delegation, a chicken, a buffalo, a goat or a crow. These animals are then chased as far away as possible from the dwelling areas. Animal substitution finds its most classical expression in the 'expiatory sacrifice', the application of which to therapeutics is no more than a particular case. The victim is burdened with the illness at the same time it is immolated as an offering 


\title{
C. Coury
}

to the deity whom it is advisable to appease. In this sacrificial medical redemption, the priest plays a part similar to that of the Angel at the time of Abraham's sacrifice. Quite often, besides, is sacrifice only one of the stages of medical action. Thus, for the purification of a leper, Leviticus (XVI, 5-7) enjoins the sick man to wash, to shave and live apart for seven days; and on the eighth day the expiatory sacrifice of a lamb takes place in front of Jahveh. ${ }^{1}$

Among Celts and the Norse, a malady was readily transferred to a tree-oak or fir, considered as a deity; objects having been in close contact with the patient (his clothes for example), were hung to its branches. Elsewhere, the receiver was an anthropomorphous effigy, painted on a wall or sculpted-an object belonging to another person or to the sorcerer himself, a nail ceremoniously driven into a tree or a wall, even a simple stone more or less sacred. The substitutive therapeutic purification may be promoted by a reputedly difficult method, such as walking along a narrow corridor, or crossing a rocky pass, or going through a pierced flagstone-the physical obstacle catching the illness on the way.

This form of therapy remained common all through ancient times. Marcellus Empiricus, a Christian physician from Bordeaux, who in Rome was minister to Theodosius, still gives in his De Medicamentis (end of the fourth century) numerous folk recipes of transference from a sick man to an inanimate object. He recommends for instance to treat warts by rubbing them on small pebbles; these should be wrapped in the leaf of an olive-tree and thrown on the highway where they will transmit the ailment to those who will pick them up. The belief in a liberating contagion did not fail to be encouraged by cases of true contagion which were misinterpreted.

A very closely related ritual, rather peculiar to Indonesia and India, consists of getting rid of the demons causing epidemics by conjuring them out and moving them away on board a material vehicle-a wagon or a boat. In the Moluccas, diseases are invited to settle for ever in a small sailing-boat built by the population. Frazer cites one of the formulae used on this occasion:

\begin{abstract}
$O$ all ye sicknesses, ye small poxes, agues, measles, etc., who have visited us so long and wasted us so sorely, but who now cease to plague us, we have made ready this ship for you and we have furnished you with provender sufficient for the voyage ... Depart, and sail away from us directly; never come near us again, but go to a land which is far from here. Let all the tides and winds waft you speedily thither, and so convey you thither that for the time to come we may live sound and well, and we may never see the sun rise on you again.
\end{abstract}

Another application of the substitutive method consists in deceiving the demon of

\begin{abstract}
1 There is no room in this account for voluntary dental mutilations (prehistoric Europe, Precolumbian America, tribes of the Gaboon), nor for sexual mutilations (emasculation, infibulation, urethral subincision, circumcision). Very obscure in many respects, their meaning is more of religious, sociological or esthetic nature than of medical character. Most of them are the expression of a symbolic sacrifice. Such is probably also the case with finger mutilations represented in painting in several Aurignacian caves in France and Spain. Prescribed by Jahveh to Abraham and all his male descendants, the section of the prepuce has first marked a sign of alliance by blood, before it became a measure of hygiene and protection. The mural representations of personages bearing glansprotectors (Tassili and Rhodesia frescoes), tend to prove that male circumcision is of very ancient use among African tribes. In the case of the young girls of Central Africa, the yearly collective excision of the clitoris and the labia minora belong to a whole group of puberty initiations. Similarly, the amputation of the right breast among the Amazons probably had a magico-religious character. Mayan, Inca and Aztec teeth, inlaid with jade, turquoise or obsidian, were an ornamental privilege of the noble class, as were jewels stuck in the nostrils or the ears.
\end{abstract}




\section{Basic Principles of Medicine in the Primitive Mind}

disease by sham, or at least in diverting him skilfully from his victim. StephenChauvet relates in this connection a very uncommon procedure which was still in use in the eighteenth century among the Waruas of Lake Tanganyika in cases of meningitis. Since this illness was thought to be caused by a demon devouring the patient's brains, the treatment consisted in deceiving his appetite by using a receptacle sculpted in the shape of a head and filled with cerebral matter taken from a dead man or from an animal. Transference in this case is ruled by the law of similarity.

Certain magic objects are credited with a preventive action against diseases, either by absorbing them or by repelling them. They are of three kinds: the amulets, the fetishs and the talismans.

The 'amulets' appear to have existed as early as prehistoric times. They play a passive protecting part and often act by virtue of a more or less remote analogy: teeth act as a protection from dental decay or from the bite of wild beasts; eye-shaped or limb-shaped objects guard an individual against illnesses attacking these organs; open hands ensure divine protection; representations of the genitals safeguard potency or fecundity. 1

'Talismans' are nothing but the material vehicles of magic forces often represented by an engraving or a written formula (conjuration sentence, fragment of a sacred text, etc.). Charms, and other protecting medals are a testimony to their survival in the most developed spheres. In a wider sense, the talisman is eventually identified with the power it represents, and this in function of its nature (gem, coral) or its particular shape. Independently from their distinctive and identifying tribal meaning, body painting (natives of America), scarifications (Black Africa), and indelible tattoos (Burma, New Zealand, Polynesia, Saharian tribes), sometimes assume a protective value. They contribute to frighten the demons and keep them out of the way. In such a case the individual makes a real talisman of his own skin. The nose-piece made of bone which the Papuans use for the transfixion of the nasal septum is less a traditional ornament than it is a mechanical means of protection from inhalation of evil spirits.

The 'fetish' differs fundamentally from the preceding objects; it represents by itself the protecting deity. As a consequence, it is open to offering or to prayer, and plays an active part. Some of them, like the Kondé fetishs in the Congo, incarnate the evil spirit. Others, on the contrary, like the 'namogangas' of the Mayombe tribes, shelter a benevolent genius, enemy of sickness and agent of recovery. Among the Loangos, so as to be conscious of their duties and prove active, these wooden fetishs need to be stimulated by nails with which physicians pierce them while offering them a prayer.

In this vast sum of therapeutic procedures common to most primitive medical systems, the least demanding scientific mind cannot see anything more than a web of obscure beliefs, a mosaic of folk customs, a set of childish and ineffective practices.

In all fairness, however, the final judgment we should pass on them cannot be restrictive. In the absolute of present scientific truth, it can only be extremely severebut the verdict must be more moderate if one consents at all to detach oneself from the present and to momentarily adopt criteria of relativity. A concept is only irrational

\footnotetext{
1 These organomorphous objects must be differentiated from the ex-votos in shape of organs offered to the deity, either to support a propitiatory medical prayer, or as a token of gratitude for a recovery. These have always abounded in the sanctuaries reputed to be miraculous, in the temples to Asklepion as well as in Christian churches.
} 


\section{Coury}

in function of the postulates on which the reasoning rests. Now, these vary according to time and place. Very fortunately, they come under the influence of the collective mental development and of the acquisitions of science, which progressively reduces the margin of hypothesis and fancy. In Greece, Heraclitus of Ephesus has been able to build up a medico-philosophical theory on the principle of co-reality, which in itself we find extremely difficult to comprehend. The essence of traditional Chinese medicine is based on the theory of contradictory simultaneities in binary opposition, and upon the dualistic conflict between Yin and Yang. The Cartesian mind, which Western Europe regards as the very expression of rationalism, refuses irrevocably to compound with such intellectual systems. But as a matter of fact, nothing allows us to assert that it is in any way superior; it is only better adapted to our mental mechanism, Primitive medicine also relies on a way of thinking which is very different from ours, to the extent that it subordinates facts to faith. However, the great principles I have recalled above, help us to comprehend it better. Many practices which we are tempted retrospectively to consider as absurd, are so only in appearance when one views them in the context of the time and climate that saw them rise. Each of them has an explanation-the difficulty only consists in discovering that explanation. Upon the whole, as River and Ackerknecht point it out, only the etiologic and pathogenic premises on which the medicine of primitive societies is based are erroneous. Actually, the therapeutic conclusions they draw from them are logical and their applications rational, taking into account the starting point postulates.

Rich with teachings for archaeologists and ethnographers, archaic or folk medical disciplines do not deserve, on the part of contemporary physicians, either a final judgment or a total and contemptuous neglect. Their study enables us better to face the more or less disguised remnants of medical superstition and to fight them with full knowledge of the facts; strongly anchored in the mind of many a patient, they condition to a great extent their intimate psychology, and sometimes even exert an influence on their behaviour. On both these grounds, the succinct retrospective evocation I thought worth doing will doubtless arouse interesting meditations among practitioners, bring about fruitful parallels, and start useful reflections.

From the stock common to most primitive medical practices, the development of the profession has been slow, hazardous and irregular; interrupted with leaps forward and sudden retreats. Empiricism progressively outpaced theurgy; medicinal preparation took the lead over magic invocation; observation finally prevailed over divination. But the decisive step was only taken about ten centuries later, when the Hippocratic Collection marked the necessary divorce between medicine and religion.

This separation, however, has not entirely been sanctioned by facts. Even outside the countries which did not come under the influence of Mediterranean civilizations, the belief in the intervention of the supernatural in medicine survived all through the Middle Ages and beyond. The esotericism of ancient times continued through Cabala and alchemy. The obscure and mystic Christianity of the first centuries went back to the old practice of exorcism, and more or less openly substituted for the cult of the physician-gods that of the healer-saints-never did the folk belief completely cease to trust hagiotherapy. The kings of France and England held from God the power of curing scrofula by prayer and imposition of hands. Indifferent to the enlightenment 


\section{Basic Principles of Medicine in the Primitive Mind}

of the Renaissance and the classical age, malevolent sorcery and medical magic pursued their obscure competition even in defiance of the stake and its flames.

In a form somewhat renovated by the taste of the day and the discovery of electromagnetism, the craze for mysterious treatments regained strength at the end of the eighteenth and at the beginning of the nineteenth century. The German mysticoromanticism has widely encouraged this medical neo-archaism. Even in the present day, the strange, the supernatural and the wonderful still exert a very strong attraction on the restless mind of a certain public; the invisible power which once spread through the voice of the magician has now passed into the hands of the magnetizer, the wand of the radiationist, the fingers of the quack, the percussion of the hammersmith.

The census of 1932 in the United States showed 32,000 'empirics', as opposed to 142,000 graduate physicians (Shryock). In France, their number has recently been estimated at approximately 10,000-and the other European countries have nothing to envy us in this field.

Two main reasons explain the survival and secular vogue of many primitive remedies. One is due to the very late birth of scientific therapy. As for the other, we have to admit that these elementary procedures often gave satisfaction to their users. In the numerous illnesses totally or partly ascribable to a psychosomatic disorder, any treatment is efficient provided only that the patient believes in it; power of suggestion is indeed considerable in medicine. It would however be a great mistake to retain only the psychological effect and to compare indiscriminately all archaic prescriptions with simple placebos. Many a drug or a mixture, the action of which was deduced from empiricism and still escapes us, must have had a true efficacy. Recent pharmacological research has amply established that certain plants used in ancient times or by the native populations of Asia, Africa and America, contain active and sometimes potent elements, so far not appreciated, which the most modern pharmaceutical industry hastens to exploit.

Yet, facing this interesting but limited contribution stand heavy liabilities: the regrettable place which primitive medical concepts and a liking for mystery still occupy in fact, and the baleful influence they exert on certain minds. This explains the blind confidence too often placed in medicinal formulae or in therapeutic methods which their 'inventors' wish to keep secret. This is a very serious fact, since it lets hazardous attempts of ill-inspired scientists take their course, when it is not a case of sheer fraud conceived by unscrupulous charlatans.

In our time when scientific medicine offers its most perfect achievements, magic and miracle-workers continue to prevail under various labels, both in the most isolated fields and in the big cities. The favour enjoyed by the 'empirics' is due to this hope in supernatural interventions which for milleniums has inspired many minds, whether simple or dissatisfied with human conditions.

It is not my intention to bring up again this disquieting subject which Professor Bariéty and I have approached in a recent book. I only beg, as a conclusion to the present study, to quote a passage of it: 'Bastard child of primitive magic, nourished by the help of human credulity and the long erring ways of medical science, empiricism in its various forms still remains the sickness of our time, and does not seem about to disappear.' 


\section{Coury}

\section{BIBLIOGRAPHY}

ACKerkneCht, E. H., 'Primitive medicine and culture', Bull. Hist. Med., 1942, 11, 503-21; 12, 545-74.

ACKERKNECHT, E. H., 'Natural diseases and rational treatment in primitive medicine', Bull. Hist. Med., 1946, 19, 467-97.

Alajouanine, Th., and Thurel R., 'Pertes de substances crâniennes consécutives à un traumatisme fermé,' Rev. Neurol., 1945, 77, 71-77.

BARIETY, M., and COURY Ch., 'Les grandes études historiques', Histoire de la Médecine, Paris, Fayard, 1963.

BologA, V. L., 'Eléments de médecine hiératique et empirique du La Tène Dace', XVIe Cong. int. d'Histoire de la Médecine, Montpellier, 1958.

Bonneu, B. N., Tatouage en général. Vie de l'homme da travers ses tatouages, thèse, Paris, 1951.

CARL, A. and PeTrT, 'Sahara oriental. Techniques chirurgicales et médicales chez les Ounias', Aesculape, 1956, 39, July-September, pp. 2-63.

Castiglion, A., Incantesimo e Magia, Milan, 1934.

Contenau, G., La Médecine en Assyrie et en Babylonie, Paris, Maloine, 1938.

Coury, Ch., 'Les médecines primitives; leur passé, leur présent', Acta 66, no. 1, pp. 3-27.

Dagand, H., and Le Goarant, 'Le tatouage thérapeutique', Aesculape, 1933, 23, June, pp. 151-152.

Disselhof, H. D., Les Grandes Civilisations de l'Amérique ancienne, Paris, Arthaud, 1963.

Frazer, J. G., Le Bouc émissaire, Paris, P. Geuthner, 1925.

Frazer, J. G., Le cycle du 'Rameau d'Or'. Le Roi magicien dans la société primitive, Paris, P. Geuthner, 1935.

Gelfand, M., 'Le "Nganga" africain', Abottempo, 1964, 2, 30-34.

Ghaloungui, P., Magic and Medical Science in Ancient Egypt, London, Hodder \& Stoughton, 1963.

Grober, J., 'Croyances et maladies chez les Primitifs', Münch, med. Wschr., 1957, 99, 957-962.

Guerra, F., 'Maya Medicine', Med. Hist., 1964, 1, 34-44.

GuERrA, F., 'Aztec medicine', Med. Hist., 1966, 4, 315-338.

GuIARD, E., La trépanation crânienne chez les Néolithiques et chez les Primitifs modernes, thèse, Bordeaux, 1929-1930.

Hagen, V. W., von, Les Royaumes du Soleil, Paris-Bruxelles, Sequoia, 1963.

HuARD, P., 'Les Médecines africaines populaires', Concours Médical, 1959.

Kerharo, J., and Thomas, L. V., 'La médecine et la pharmacopée des Diola de BasseCasamance (Sénégal)', Bull. Soc. Méd. Afr. Noire, 1962, 7, 669-702.

KIDD, G. E., 'Trephining among primitive Indians of British Columbia', Can. Med. Ass. J., 1946, 55, 513-16.

Kouadjo-Tiakoh, G., La Médecine des Guérisseurs noirs de l'Ouest africain, Paris, Foulon, 1950.

LABAT, R., 'La médecine assyro-babylonienne', Rev. Hist. Méd. hébr., 1963, 61, 101-117.

LACASSAGNE, 'Le tatouage ornemental', Aesculape, 1933, 23, October, pp. 259-263.

Hontan, Baron De LA, Dialogues curieux et Mémoires de l'Amérique Septentrionale, Baltimore, The Johns Hopkins Press; Paris, A. Margraff, 1931, pp. 124-131.

LASTRES, J. B. DE, and CABIESEs F., La Trepanacion del craneo en el Antiguo Peru, Lima, 1960.

Double, A. F. LE, 'La Médecine et la chirurgie dans les temps préhistoriques', France Méd., 1911.

Lestrange, M. De, 'Devins et médecins en Afrique Noire', Conc. Méd., 1955, 77, 89-95.

Levi-Strauss, C., Tristes Tropiques, Paris, Plon, 1955.

MARRI, F. G., 'Trépanation crânienne préhistorique ou ostéomyélite de la voute du crâne chez l'homme préhistorique'. Sem. Hôp. Paris, July-August 1946, pp.121-126, 140-145.

Masson, L., 'La Médecine chez les Druides', Aesculape, 1934, 24, November, pp. 283-287.

Montagu, F. A., 'Primitive medicine', New Engl., J. Med., 235, no 2, pp. 43-49. 
Basic Principles of Medicine in the Primitive Mind

Morkl, P., Pathologie et Chirurgie préhistoriques, Marseille, Moullot, 1964.

Necrasov, O., Floru, E., and Nicolaescu-Plopsor, D., 'Contributions à l'étude de la trépanation chez les populations préhistoriques du territoire de la République populaire roumaine', Prezglad Antropolagiczny, 1959, 25, 11-32.

Pazzin, A., La Medicina primitiva, Rome, Arte e Storia, 1941.

Randriamaro, T.,'La Médecine à Madagascar aux temps fabuleux de son histoire', Scalpel, Bruxelles, 1952, 105, 1285-1291.

Russu, I. G., and BologA V., 'Trepanationen im Gebiet des heutigen Rumänien', Sudhoffs Arch. Gesch. Med. Naturw., 1961, 45, 34-66.

SAlhy, A., 'Mains mutilées: mystère de la Préhistoire', Abbottempo, 1965, 2, 24-29.

Sasportas, 'Le guérisseur indigène à Tahiti', Aesculape, 1924, 14, October, pp. 237-241.

Sigrrist, H. E., A History of Medicine, Vol. I: Primitive and archaic medicine, New York, Oxford University Press, 1951.

Soustrule, J., La Vie quotidienne des Aztèques à la veille de la conquête espagnole, Paris, Hachette, 1955.

StBPHen-ChaUVET, La Médecine chez les peuples primitifs (préhistoriques et contemporains), Paris, Maloine, 1936.

Taton, R., et al., La science antique et médiévale, in Histoire générale des sciences, tome I, Paris, Presses Universitaires de France, 1957.

Zuniga-Cisneros, M., Historia de la Medicina, Caracas-Madrid, Edit. Edime, 1960. 